Participative Journal: Jurnal Pengabdian Pada Masyarakat

Volume 1, Nomo 2, Oktober 2021| Page 112-122

E-ISSN 2776-2971, P-ISSN 2776-5954

DOI: https://doi.org/10.55099/pj.v1i02

Journal homepage: https://jurnal.jurmat.com/index.php/pj/index

\title{
Peningkatan mutu pembelajaran melalui implementasi media pembelajaran berbasis lesson study
}

\section{Sofyan Mahfudy ${ }^{1}$, Kurniawan Arizona ${ }^{2}$}

Affiliasi: Universitas Islam Negeri Mataram, Mataram, Indonesia

\begin{abstract}
A b s t $\mathbf{r}$ a $\mathbf{c}$ t: Teacher professionalism plays an important role in education because it determines the quality of teaching and learning in the classroom. One aspect of teacher professionalism is the ability to design good learning and skills in using learning media to increase learning effectiveness. The existing phenomenon is that teachers are not optimal in designing lesson plans that utilize attractive and interesting learning media. Therefore, efforts are needed to improve the ability of teachers in designing good lesson plans by utilizing learning media. This community service aims to provide understanding and knowledge to teachers in utilizing the media as a learning tool and applying the principles of lesson study to the learning process. The service is carried out in two stages, namely training in the form of workshops and mentoring for model teachers. The results of the mentoring show the teacher's understanding of the importance of using learning media. In addition, teachers also have knowledge in designing learning with the principle of lesson study to be applied in the implementation of learning in the classroom.
\end{abstract}

Keywords: teacher professionalism; instructional Media; lesson study

A b s t r a k: Profesionalisme guru memegang peranan penting dalam pendidikan karena
menentukan kualitas pelaksanaan pembelajaran dan pengajaran di kelas. Salah satu aspek
profesionalisme guru adalah kemampuan merancang pembelajaran yang baik dan
keterampilan dalam menggunakan media pembelajaran untuk meningkatkan efektivitas
pembelajaran. Fenomena yang ada, guru belum optimal dalam merancang rencana
pembelajaran yang memanfaatkan media pembelajaran yang atraktif dan menarik. Oleh
karena itu, diperlukan upaya untuk meningkatkan kemampuan guru dalam mendesain rencana
pembelajaran yang baik dengan memanfaatkan media pembelajaran. Pengabdian kepada
masyarakat ini bertujuan untuk memberikan pemahaman dan pengetahuan kepada guru
dalam memanfaatkan media sebagai sarana belajar dan diterapkan dengan prinsip-prinsip
lesson study pada proses pembelajaran. Pengabdian dilakukan melalui dua tahapan yaitu
pelatihan dalam bentuk workshop dan pendampingan bagi guru model. Hasil pendampingan

${ }^{1}$ Coresponden to author: Fakultas Tarbiyah dan Keguruan, Universitas Islam Negeri Mataram, Jl. Gajah Mada Jempong, Indonesia. (83116),e-mail addresses: sofyan_mahfudy@uinmataram.ac.id

22E-mail addresses: arizona@uinmataram.ac.id

Sofyan Mahfudy \& Kurniawan Arizona (2021) "Peningkatan mutu pembelajaran....... Vol. 1, No. 2, 2021 | h. 112 
menunjukkan adanya pemahaman guru terhadap pentingnya penggunaan media pembelajaran. Selain itu, guru juga memiliki pengetahuan dalam merancang pembelajaran dengan prinsip lesson study untuk diterapkan pelaksanaan pembelajaran di kelas.

Kata kunci: profesionalisme guru; media pembelajaran; lesson study

\section{Pendahuluan}

Perguruan tinggi sebagai salah satu institusi yang ada di Indonesia mengemban amanah untuk menjawab tantangan zaman yang semakin kompleks. Dalam konteks tersebut, perguruan tinggi harus mampu menjadikan dirinya sebagai pusat pengembangan dan penyeb arluasan Ilmu Pengetahuan dan Teknologi (IPTEK) serta mengupayakan penggunaannya untuk meningkatkan taraf kehidupan masyarakat. Hal tersebut merupakan bagian dari tugas dan fungsi perguruan tinggi yang termaktub di dalam tri dharma perguruan tinggi.

Universitas Islam Negeri (UIN) Mataram sebagai salah satu perguruan tinggi di bawah Kementerian Agama senantiasa berupaya memainkan peran dan fungsinya di masyarakat secara nyata. Hal ini dikarenakan perubahan dan dinamika kehidupan sosial masyarakat yang begitu cepat menuntut respon yang cepat pula. Salah satu respon tersebut dapat diwujudkan melalui program pengabdian masyarakat yang setiap tahun dilakukan UIN Mataram. Melalui dharma pengabdian masyarakat, UIN Mataram diharapkan melakukan pelayanan kepada masyarakat untuk mempercepat proses peningkatan kesejahteraan dan kemajuan masyarakat. Salah satu bidang yang menjadi konsen kegiatan pengabdian tersebut adalah bidang pendidikan dan pengajaran terutama di lingkup madrasah. Melalui kegiatan tersebut akan diperoleh pula feedback dari masyarakat tentang tingkat kemajuan dan relevansi ilmu yang dikembangkan UIN Mataram.

Problem yang terjadi di madrasah-madrasah khususnya Kota Mataram adalah berkaitan dengan perencanaan dan implementasi pembelajaran. Secara umum apa yang dilakukan guru dalam pembelajaran di madrasah masih dilandasi metode transfer informasi, yaitu memindahkan secara utuh pengetahuan yang dimiliki guru ke pikiran peserta didik. Guru mencoba memfokuskan pada upaya menuangkan pengetahuan yang dimilikinya sebanyak mungkin kepada peserta didik. Guru terkesan hanya mengejar materi dan takut kalau ada materi yang disampaikan tidak habis. Hal ini berdampak pada kurangnya pengalaman langsung peserta didik dalam proses belajar, sehingga peningkatan hasil belajar mereka kurang optimal. Kondisi semacam ini dapat menyebabkan kegiatan belajar peserta didik menjadi kurang bermakna. Hal yang hampir sama juga terjadi di MA Plus Abu Hurairah Mataram NTB³ . Beberapa hasil riset yang dilakukan terhadap proses pembelajaran di madrasah juga menunjukkan hasil yang tidak jauh berbeda dengan kondisi tersebut. Kuantitas dan kualitas tenaga pengajar atau guru di madrasah masih belum baik (Huda, 2016).

Banyak upaya yang dapat dilakukan agar proses pembelajaran menjadi lebih menarik dan mampu mengoptimalkan hasil belajar peserta didik. Salah satu faktor terpenting dalam upaya

${ }^{3}$ Hasil wawancara dengan guru dan observasi di MA Plus Abu Hurairah Mataram pada bulan Maret 2018

Sofyan Mahfudy \& Kurniawan Arizona (2021) "Peningkeatan mutu pembelajaran.......| Vol. 1, No. 2, 2021 | h. 113 
tersebut adalah keterlibatan peserta didik secara aktif dalam proses pembelajaran. Peserta didik terlibat secara aktif dalam mengamati, mengoperasikan alat, atau berlatih menggunakan objek konkret sebagai bagian dari pelajaran. Untuk mencapai tujuan tersebut, diperlukan langkahlangkah mendasar, konsisten, dan sistematik. Salah satunya adalah penggunaan media pembelajaran yang tepat (Handayanto, 2003). Media secara harfiah dapat diartikan sebagai perantara atau pengantar pesan dari pengirim kepada penerima pesan (Arsyad, 2013). Media yang baik hendaknya dapat dimanipulasi, dapat dilihat, didengar, dan dibaca (Sadiman, 2012). Dalam artikel ini media pembelajaran dapat didefinisikan sebagai wahana atau sarana untuk menyampaikan informasi belajar kepada pembelajar (siswa) secara efektif dan efisien.

Penggunaan media pembelajaran baik secara individu maupun kelompok akan memberi peluang kepada peserta didik untuk lebih aktif dalam kegiatan pembelajaran. Melalui media pembelajaran hal yang bersifat abstrak bisa menjadi lebih konkret (Sanjaya, 2011). Selain itu, penggunaan media pembelajaran dapat memperjelas penyajian pesan dan informasi sehingga dapat memperlancar dan meningkatkan proses dan hasil belajar. Media yang ingin ditekankan pada pengabdian ini adalah media realmaupun virtual. Media real merupakan media sesungguhnya yang dapat diamati secara langsung oleh panca indera yang mempunyai peranan penting untuk memberikan pengalaman secara nyata, memperlancar proses belajar dan mengoptimalkan indera-indera para peserta didik terhadap suatu obyek tertentu. Sedangkan media virtual merupakan media pembelajaran yang berbasis internet sehingga mampu mengefisiensikan dan mengefektifkan jarak dan waktu. Aktivitas pembelajaran dilakukan siswa secara online (dalam jaringan).

Penggunaan media real merupakan cara yang cukup efektif, karena dapat memberikan informasi yang lebih akurat. Beberapa penelitian membuktikan bahwa pembelajaran yang diserap melalui media penglihatan (media visual), terutama media visual yang menarik, dapat mempercepat daya serap peserta didik dalam memahami pelajaran yang disampaikan. Media real lebih mudah diingat dibandingkan dengan media pembelajaran yang hanya berupa text book. Karena jenisnya yang beragam, guru dapat menggunakan media real yang variatif, dan tidak membosankan bagi para peserta didik. Misalnya dalam pelajaran IPA, saat mempelajari anatomi tubuh manusia, peserta didik dapat diminta maju ke depan, melihat model anatomi lebih dekat, dan diminta untuk menunjukkan satu bagian yang diminta oleh gurunya.

Hasil penelitian di madrasah juga merekomendasikan akan pentingnya penggunaan media dalam pembelajaran karena mampu meningkatkan motivasi belajar siswa di madrasah (Putri, 2017). Penggunaan media akan dapat membantu meningkatkan kualitas pembelajaran (Munirah, 2014). Hasil penelitian Syukri (2017) terhadap ayat-ayat pembelajaran dalam Al-Qur'an juga menunjukkan bahwa konsep pembelajaran menurut Al-Qur'an ternyata lebih bernuansa konkrit daripada abstrak-verbal. Lebih lanjut dalam kesimpulan penelitiannya Syukri menekankan dan merekomendasikan agar setiap guru (instruktur) menyertakan media konkrit-simbolis dalam proses pembelajaran.

Salah satu pendekatan yang mampu meningkatkan mutu pembelajaran adalah lesson study. Lesson study merupakan suatu pendekatan peningkatan kualitas pembelajaran yang dilaksanakan 
oleh guru secara kolaboratif dengan langkah-langkah pokok merancang pembelajaran untuk mencapai tujuan, melaksanakan pembelajaran, mengamati pelaksanaan pembelajaran tersebut, serta melakukan refleksi untuk mendiskusikan pembelajaran yang dikaji tersebut untuk bahan penyempurnaan dalam rencana pembelajaran berikutnya (Hendayana, 2007). Fokus utama pelaksanaan lesson study adalah aktivitas peserta didik di kelas, dengan asumsi bahwa aktivitas peserta didik tersebut terkait dengan aktivitas guru selama mengajar di kelas.

Penerapan lesson study didasarkan pada proses dan usaha yang berkesinambungan. Proses yang asli dan nyata, bukan tampil karena hanya untuk diamati. Kondisi natural inilah yang diyakini dapat membuat ilmu yang diperoleh tidak pernah dilupakan peserta didik. Guru harus merubah cara menyampaikan ilmunya, dari yang bersifat klasikal (penyampaian materi) menjadi eksploratif (pemahaman arti suatu ilmu). Keaktifan peserta didik dalam bereksplorasi tidak akan terganggu oleh banyaknya pengamat yang hadir di dalam kelasnya. Pada akhirnya lesson study tidak hanya menghasilkan pembelajaran yang baik, tetapi juga membangun kapasitas, keahlian, dan pengetahuan guru untuk mengembangkan pengajaran dan pembelajaran dalam disiplin dan bidang yang lebih luas (Cerbin \& Crosse, 2006).

Hasil penelitian juga menunjukkan bahwa lesson study mampu meningkatkan mutu pembelajaran. Lesson study mampu meningkatkan pengajaran dengan mengembangkan pengetahuan guru (materi pelajaran, kemampuan pedagogik, dan kemampuan berpikir siswa), dengan membangun komunitas guru profesional, dan dengan meningkatkan materi atau bahan ajar (Lewis, Perry \& Hurd, 2009). Guru-guru yang berpartisipasi dalam proyek lesson study menemukan pengalaman berharga dan belajar banyak selama proses keterlibatan dan kegiatan pengamatan dengan kolega mereka di kelas (Fernandes, 2002).

Adanya kegiatan pengabdian masyarakat dalam upaya peningkatan mutu pembelajaran melalui pemanfaatan media pembelajaran berbasis lesson study menjadi salah satu inspirasi dalam proses pembelajaran di madrasah khususnya di MA Plus Abu Hurairah Mataram. Oleh karenanya, pelaksanaan pengabdian masyarakat program madrasah binaan menjadi hal yang penting untuk dilakukan sebagai upaya untuk meningkatkan kualitas pendidikan terutama pendidikan di lembaga pendidikan islam.

\section{Metode}

Untuk mengatasi belum optimalnya penggunaan media dalam pembelajaran dan juga pembelajaran yang cenderung tradisional, maka metode yang digunakan dalam pengabdian ini adalah pelatihan dan pendampingan. Dalam pelaksanaan pengabdian ini kegiatan menjadi dua bagian besar yaitu pelatihan dalam bentuk workshop dan pendampingan. Pelatihan dalam bentuk workshop dimaksudkan agar peserta dalam hal ini guru memiliki pemahaman yang benar serta pengetahuan yang cukup tentang materi pengabdian yaitu media dan lesson study. Dengan menghadirkan dua narasumber yang kompeten di dua bidang tersebut, peserta dapat memperoleh informasi yang luas tentang media pembelajaran dan lesson study. Pelatihan dalam bentuk workshop telah diselenggarakan pada hari Sabtu, 22 September 2018 yang bertempat di Madrasah Aliyah Plus Abu Hurairah Kota Mataram. Sementara pendampingan dimaksudkan apa

Sofyan Mahfudy \& Kurniawan Arizona (2021) "Peningkeatan mutu pembelajaran....... | Vol. 1, No. 2, 2021 | h. 115 
yang telah diperoleh di workshop dapat diterapkan dalam pembelajaran di kelas melalui pendampingan oleh tim pengabdi. Pendampingan merupakan aspek penting dalam melaksanakan pengabdian sebagai bentuk kelanjutan dari kegiatan pelatihan atau workshop yang telah dilakukan.

Implementasi media pembelajaran yang berbasis lesson study dilaksanakan melalui praktik pembelajaran di kelas, artinya kegiatan pengabdian ini harus sampai kepada pendampingan kepada guru model untuk mempraktikkannya di dalam kelas bersama siswa. Nantinya pada tahap ini guru model akan menerapkan pembelajaran yang menggunakan media dan berbasis lesson study. Artinya guru model dan tim nantinya akan mencoba menerapkan pembelajaran yang sesuai dengan prinsi-prinsip lesson study yaitu perencanaan pembelajaran (plan), pelaksanaan pembelajaran (do), dan observasi pembelajaran (see) secara kolaboratif. (Catatan: Program Pendampingan masih dalam proses/in process). Adapun langkah-langkah pelaksanaan kegiatan pengabdian ini adalah sebagai berikut:

\section{Hasil dan Pembahasan}

\section{Pemetaan Masalah Sebagai Dasar Pelaksanaan Pengabdian}

Pada tahap ini, pengabdi melakukan identifikasi masalah pada madrasah yang akan dijadikan mitra binaan dalam hal ini Madrasah Plus (MA) Plus Abu Hurairah. Identifikasi masalah ini bertujuan sebagai bahan untuk mendesain kegiatan yang memiliki manfaat bagi madrasah mitra binaan dan kegiatan tersebut tepat sasaran atau dibutuhkan lembaga tersebut untuk peningkatan kualitas pendidikannya. Identifikasi dilakukan dengan cara pengabdi melakukan penggalian informasi terhadap guru MA Plus Abu Hurairah yang sudah memiliki pengalaman mengajar. Metode yang dilakukan untuk penggalian informasi adalah dengan melakukan wawancara, diskusi, dan juga pengamatan langsung suasana akademik di MA Plus Abu Hurairah Mataram. Dari informasi dan data awal tersebut, pengabdi kemudian menyusun rencana atau desain kegiatan pengabdian dalam bentuk proposal pengabdian yang kemudian diajukan kepada Pusat Pengabdian kepada Masyarakat (P2M) LP2M UIN Mataram untuk mendapatkan dana hibah bantuan pengabdian kepada masyarakat untuk kategori madrasah binaan. Pada kompetisi tersebut, proposal yang diajukan lolos untuk mendapatkan bantuan dana hibah pengabdian DIPA UIN Mataram Tahun 2018.

\section{Pembentukan Tim Panitia Pengabdian}

Pada tahap ini pengabdi membentuk tim pelaksana kegiatan yang terdiri dari beberapa teman dosen (rekan sejawat) di UIN Mataram, beberapa guru di MA Plus Abu Hurairah, dan pengabdi sendiri. Adanya kepanitian membuat pelaksanaan kegiatan menjadi lebih terarah dan lebih baik karena adanya kerja sama antar anggota. Selain itu diskusi dan adanya beberapa pendapat menjadikan beberapa detail kegiatan juga dapat direncanakan dengan baik.

Komunikasi dan Kerjasama dengan Pihak Madrasah (Mitra Pengabdi)

Pada tahap ini, pengabdi melakukan komunikasi dengan pihak sekolah yaitu Kepala MA Plus Abu Hurairah untuk menyampaikan tujuan kegiatan pengabdian dan rencana kegiatan yang akan dilakukan. Pada tahap ini kepala MA Plus Abu Hurairah menyambut positif kegiatan

Sofyan Mahfudy \& Kurniawan Arizona (2021) "Peningkeatan mutu pembelajaran....... | Vol. 1, No. 2, 2021 | h. 116 
pengabdian implementasi media pembelajaran yang berbasis lesson study. Kepala sekolah mendukung kegiatan yang akan dilakukan karena sesuai dengan visi dan misi sekolah yang senantiasa ingin meningkatkan kualitas pendidikan di madrasah tersebut yang salah satunya dengan peningkatan profesionalisme guru tenaga pengajar. Kepala sekolah memiliki harapan dengan adanya peningkatan profesionalisme guru, kegiatan pembelajaran menjadi lebih baik yang pada akhirnya siswa atau santri mampu berkompetisi dengan sekolah atau madrasah yang lain di kota Mataram. Melalui pertemuan dan komunikasi ini pengabdi mampu mendapatkan gambaran lebih lengkap tentang potensi dan sumber daya yang ada di MA Plus Abu Hurairah dan hal-hal yang belum optimal sehingga membutuhkan upaya untuk peningkatan. Selain itu, yang lebih penting lagi adalah pengabdi mendapatkan masukan dan saran terhadap rencana kegiatan yang tentunya sangat berharga bagi tim pengabdi. Pertemuan dengan kepala sekolah menghasilkan kesepakatan tentang hari dan tanggal pelaksanaan kegiatan pengabdian.

\section{Pelaksanaan Workshop}

Kegiatan workshop dilaksanakan pada hari Sabtu tanggal 22 September 2018 bertempat di ruang sidang/rapat Madrasah Aliyah Plus Abu Hurairah. Pembukaan dilaksanakan pada pukul 08.15 WITA setelah registrasi dan pengisian Curiculum Vitae (CV) oleh peserta. Acara pembukaan dihadiri oleh Kepala Bidang Akademik Pondok Abu Hurairah Drs. Hasbiallah, M.Pd.I, Kepala Madrasah Aliyah Plus Abu Hurairah Johan Saputra Halim, M.Pd.I, pengabdi dan tim, serta keseluruhan peserta workshop. Dalam kesempatan sambutannya, kabid akademik menyampaikan sangat mendukung kegiatan workshop. Kabid akademik menyatakan bahwa Pondok Abu Hurairah senantiasa membuka diri untuk semua pihak dalam konteks hal-hal yang positif. Salah satunya adalah upaya pengembangan profesionalisme guru agar kemampuan mengajarnya semakin bervariasi dan inovatif. Kabid menyatakan bahwa tantangan dan kompetisi pendidikan terutama di kota Mataram semakin ketat, sehingga Pondok Abu Hurairah sebagai penyelenggara pendidikan harus senantiasa meningkatkan mutunya. Kabid juga menghimbau kepada peserta untuk mengikuti kegiatan tersebut dengan baik sampai dengan selesai.

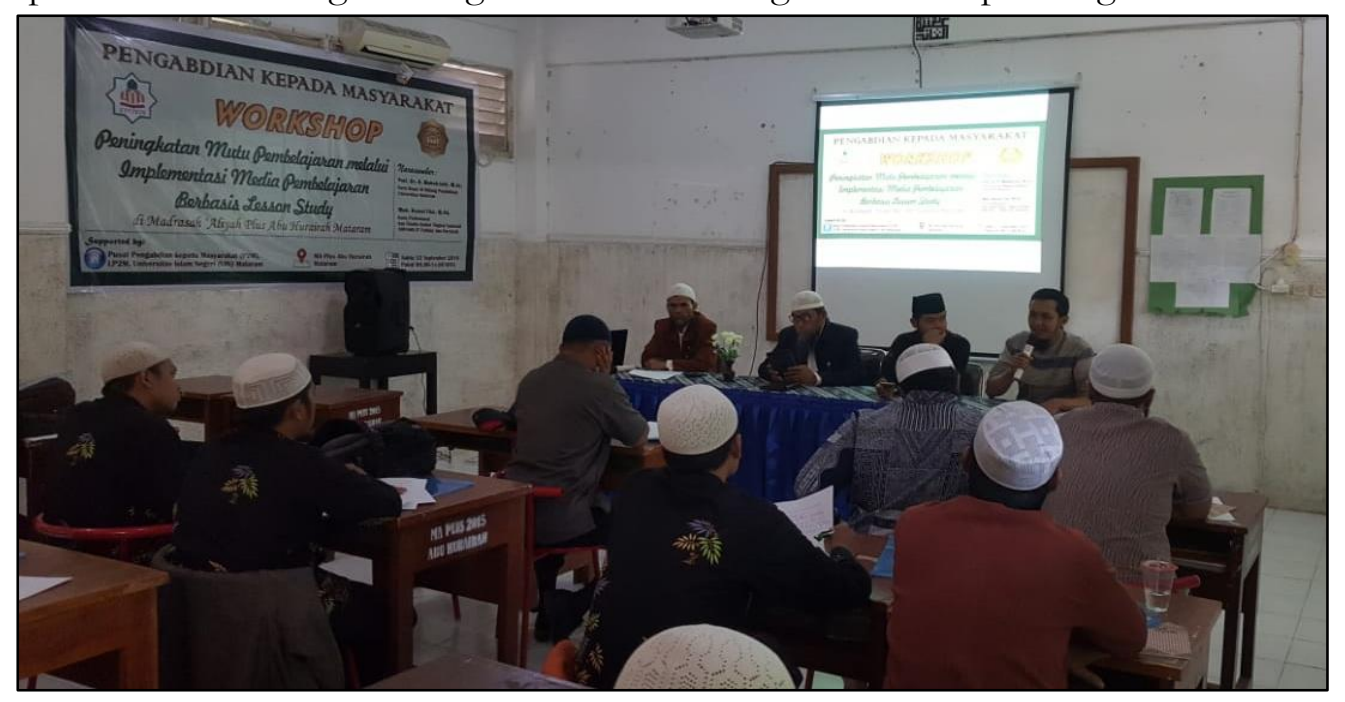

Gambar 1. Acara pembukaan workshop

Sofyan Mahfudy \& Kurniawan Arizona (2021) "Peningkatan mutu pembelajaran....... Vol. 1, No. 2, 2021 | h. 117 
Sejalan dengan apa yang disampaikan oleh Kabid Pondok Abu Hurairah, Kepala MA Plus Abu Hurairah dalam sambutannya menyampaikan sangat mendukung kegiatan tersebut. Harapannya para guru yang ada di Madrasah Aliyah Abu Hurairah mendapatkan penyegaran ilmu dalam bidang pengajaran. Dengan bekal teori yang diperoleh, kepala sekolah mengharapkan nantinya dapat dipraktikkan di dalam kelas. Kepala sekolah juga mengharapkan adanya guru model yaitu dari guru mata pelajaran agama dan guru mata pelajaran yang eksak (matematika). Guru model yang mendapatkan pendampingan diharapkan dapat menularkan pengetahuan dan pemahamannya kepada guru-guru yang lain. Selain sambutan dari Kabid kepondokan dan Kepala Sekolah, pengabdi juga memberikan sambutan yang berisi tentang pengenalan program pengabdian kepada masyarakat yang dibawahi oleh Lembaga Penelitian dan Pengabdian kepada Masyarakat UIN Mataram, penyampaian informasi terkait penetapan MA Plus Abu Hurairah sebagai lokasi pengabdian, dan tujuan kegiatan. Dokumentasi sesi acara pembukaan salah satunya nampak pada gambar 1 di atas dan juga pada lampiran..

Materi Workshop dari Narasumber Pertama

Materi pertama workshop adalah tentang Lesson Study yang disampaikan oleh narasumber pertama yaitu Prof. Dr. Abdul Wahab Jufri, M.Sc. Materi yang disampaikan adalah kajian historis lesson study, hakikat lesson study, tujuan lesson study, manfaat lesson study, dan bagaimana praktiknya dalam pembelajaran. Salah satu sesi materi adalah seperti pada gambar 2 di bawah.

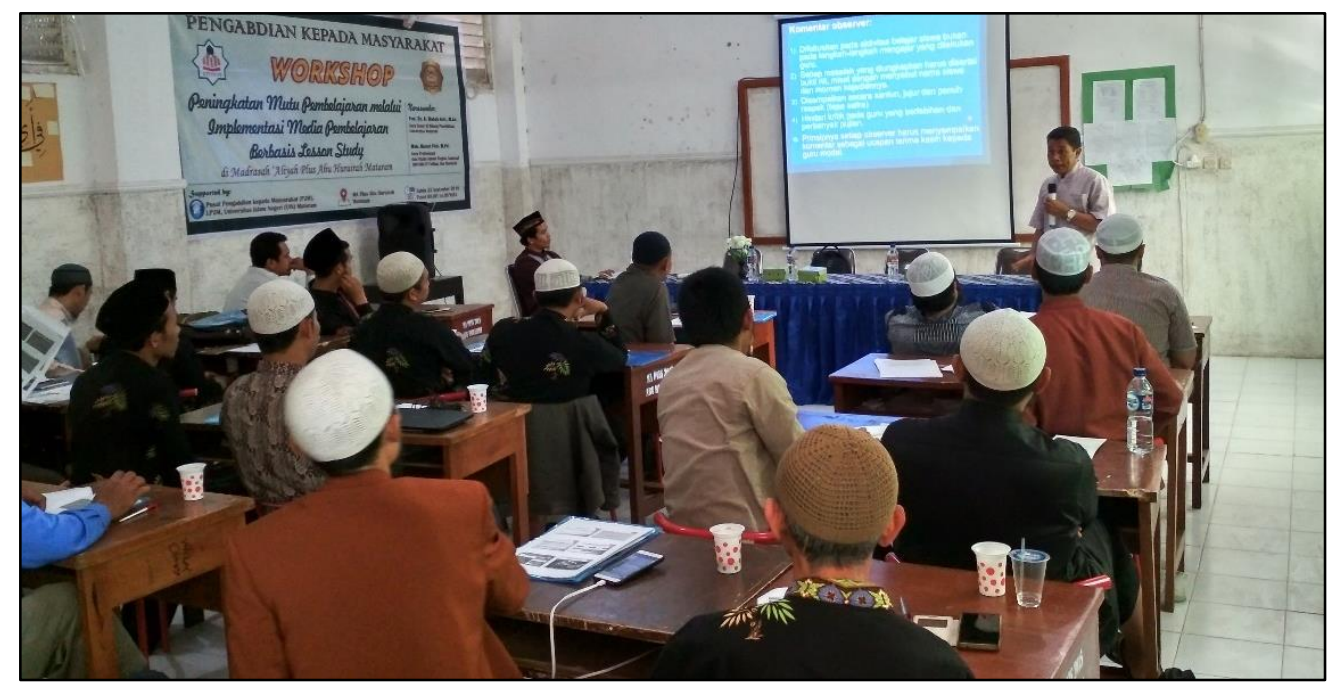

Gambar 2. Materi narasumber pertama

Inti pokok materi yang disampaikan adalah bahwa lesson study merupakan model pengembangan profesionalisme guru untuk meningkatkan kualitas pembelajaran di kelas, dilakukan oleh sekelompok guru secara kolaboratif, yang dimulai dari perencanaan pembelajaran, pelaksanaan yang dilakukan dengan observasi atau pengamatan, refleksi, dan evaluasi, dan revisi. Tiga unsur utama dalam pelaksanaan lesson study adalah plan (pelaksanaan), do (pelaksanaan), dan see (melihat dan mengevaluasi). Dengan kegiatan pembelajaran yang dilaksanakan secara

Sofyan Mahfudy \& Kurniawan Arizona (2021) "Peningkatan mutu pembelajaran....... | Vol. 1, No. 2, 2021 | h. 118 
kolaboratif oleh guru mulai dari perencanaan sampai refleksi, maka harapannya adalah kualitas pembelajaran di kelas semakin baik.

Materi kedua workshop adalah tentang media pembelajaran yang disampaikan oleh narasumber kedua yaitu Muhammad Husnul Fikri, M.Pd. Materi yang disampaikan adalah tentang hakikat media pembelajaran, manfaat media pembelajaran, perkembangan media pembelajaran, dan aplikasi-aplikasi pembelajaran yang ada di mobile edukasi Indonesia. Salah satu sesi materi dari narasumber yang kedua adalah seperti pada gambar 3 di bawah.

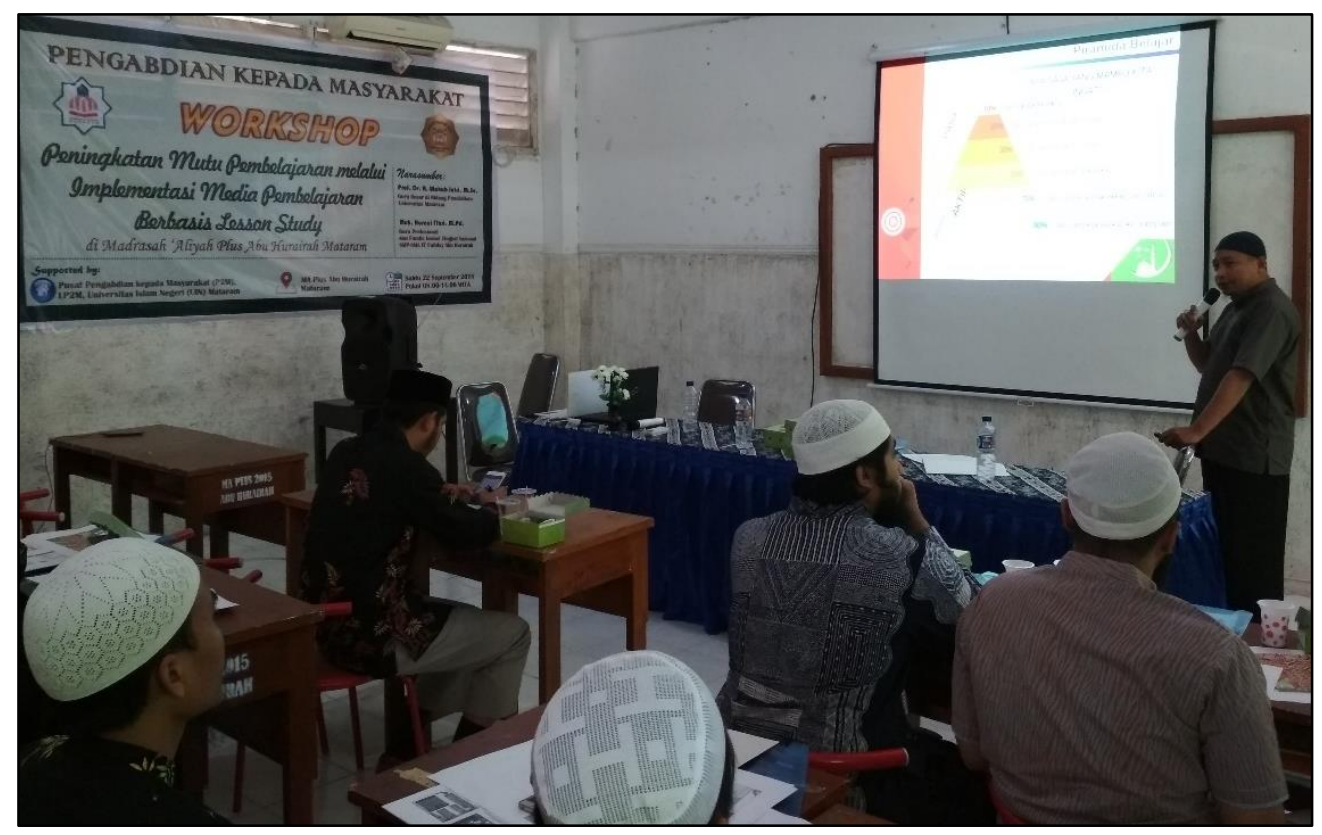

Gambar 3. Materi narasumber kedua

Pada kesempatan tersebut, guru (peserta workshop) mempraktikkan penggunaan aplikasi yang ada di laman atau website Mobile Edukasi Indonesia (https://medukasi.kemdikbud.go.id/) yang dikembangkan oleh Kementerian Pendidikan dan Kebudayaan Republik Indonesia. Guru dengan menggunakan HP android yang dimiliki dapat mengakses aplikasi yang ada dalam website mobile edukasi tersebut dan kemudian menghubungkannya dengan layar LCD sehingga dapat ditampilkan dalam proses pembelajaran di kelas. Aplikasi yang tersedia antara lain adalah mengenal bahasa arab, Fisika Siaga-Seri Hukum Pascal, Momentum dan Tumbukan, serta aplikasi pada materi yang lainnya. Pada sesi ini narasumber juga memberikan langkah-langkah untuk meng-install aplikasi mobile edukasi pada komputer atau PC laptop. Pada sesi materi yang disampaikan oleh narasumber yang pertama dan kedua, beberapa peserta mengajukan beberapa pertanyaan kepada narasumber. Adanya pertanyaan tersebut memunculkan diskusi dan membantu peserta memahami lebih baik materi yang disampaikan.

Salah satu indikator tingkat keberhasilan kegiatan ini tingkat partisipasi peserta yang sangat tinggi. Seluruh peserta undangan mengikuti dengan baik workshop yang dilakukan sampai dengan selesai. Selain itu, pemaparan materi menarik minat pertanyaan dari para guru sehingga menunjukkan antusiasme dan semangat belajar yang tinggi. Indikator lain keberhasilan program 
ini adalah guru-guru di MA Plus Abu Hurairah memiliki pengetahuan tentang media pembelajaran berbasis teknologi mobile. Guru mengetahui alamat media pembelajaran yang berbasis internet dan dapat di akses melaui mobile phone.

Dalam kegiatan pengabdian masyarakat ini, pengabdi juga menyebarkan kuesioner yang bertujuan untuk mengetahui bagaimana gambaran rencana pembelajaran yang akan mereka lakukan di kelas berdasarkan prinsip-prinsip pembelajaran yang bermutu dan menggunakan media pembelajaran. Salah satu peserta menyatakan bahwa pembelajaran yang efektif dan berkualitas adalah pembelajaran yang mampu meningkatkan pemahaman siswa terhadap materi dan mampu menjawab tantangan siswa ke depan. Hasil kuesioner peserta tersebut adalah seperti pada gambar 4 dan gambar 5 .

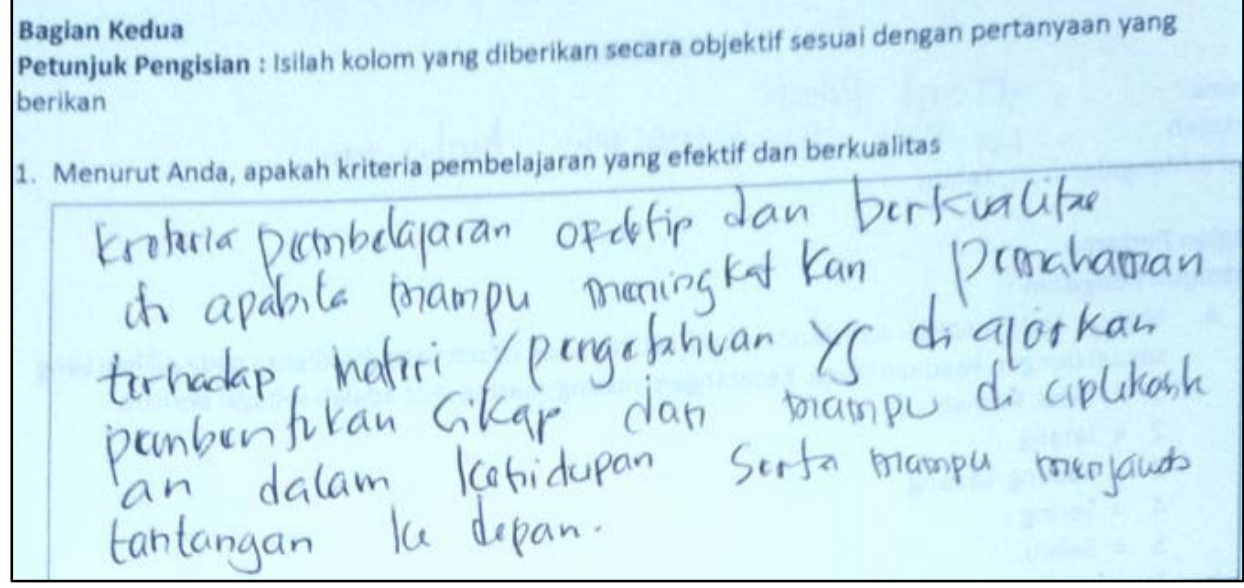

Gambar 4. Hasil kuesioner salah satu peserta

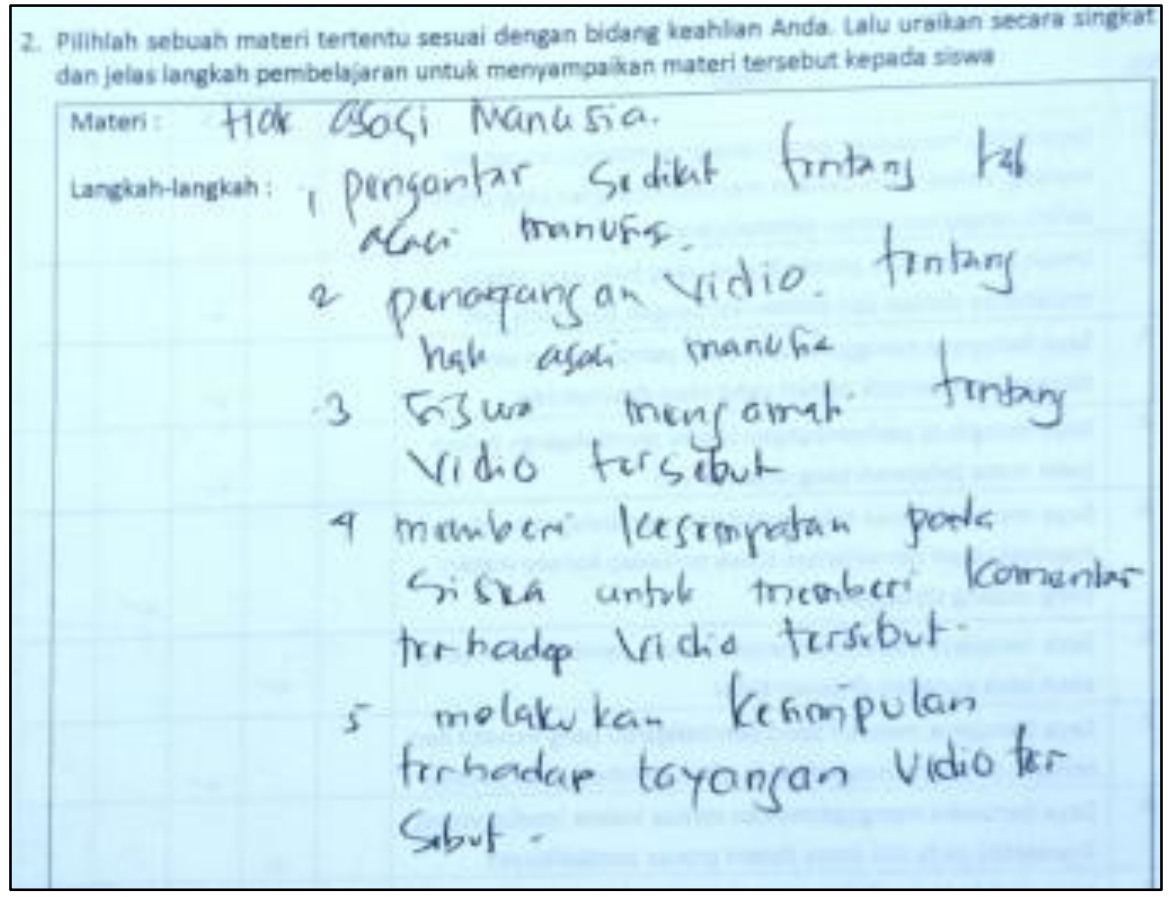

Gambar 5. Hasil kuesioner salah satu peserta

Sofyan Mahfudy \& Kurniawan Arizona (2021) "Peningkatan mutu pembelajaran.......| Vol. 1, No. 2, 2021 | h. 120 
Dari gambaran hasil kuesioner peserta di atas, terlihat bahwa guru sudah menggunakan media dalam pembelajaran. Contohnya dalam langkah pembelajaran di atas, guru menggunakan video untuk menyampaikan materi pembelajaran. Sehingga sebenarnya ada potensi yang besar guru mampu merancang pembelajaran yang lebih baik melalui berkolaborasi dengan guru yang lain. (Catatan: Hasil pengabdian yang penting yaitu Program Pendampingan bagi guru masih dalam proses/in process sehingga belum dapat direport dalam artikel ini)

\section{Penutup}

Kegiatan pengabdian kepada masyarakat dengan judul "Peningkatan Mutu Pembelajaran melalui Implementasi Media Pembelajaran Berbasis Lesson Study di Madrasah Aliyah (MA) Plus Abu Hurairah Mataram dapat terlaksana dengan baik. Kegiatan pengabdian terdiri dari dua tahapan utama yaitu pelatihan dalam bentuk workshop dan program pendampingan bagi guru model. Tahapan pelatihan dalam bentuk workshop telah selesai dilakukan, sementara tahapan pendampingan terhadap guru model sampai dengan laporan ini ditulis belum selesai dilakukan.

Pelatihan dalam bentuk workshop memberikan manfaat bagi guru yang ada di Madrasah Aliyah Plus Abu Hurairah. Para peserta yang sebagian besar adalah guru Madrasah Aliyah semangat dalam mengikuti pelatihan ini. Tingkat partisipasi peserta sangat tinggi. Keaktifan selama workshop berlangsung juga sangat baik. Minat guru untuk melakukan peningkatan kualitas pembelajaran juga sangat baik, terbukti guru antusias untuk menjadi guru model dalam proses pendampingan. Setidaknya para guru telah memiliki pemahaman yang baik terhadap manfaat media pembelajaran, bagaimana membuat media, bagaimana mencari sumber media pembelajaran di internet, dan juga pemahaman yang baik terhadap pelaksanaan lesson study untuk meningkatkan profesionalismenya.

\section{Daftar Pustaka}

Arsyad, A. (2013). Media Pembelajaran. Jakarta: PT. RajaGrafindo Persada.

Cerbin, W \& Crosse, L. (2006). Lesson Study as a Model for Building Pedagogical Knowledge and Improving Teaching. International Journal of Teaching and Learning in Higher Education. 18 (3) : 250-257

Fernandes, C. (2002). Learning from Japanese Approaches to Professional Development The Case Of Lesson Study. Journal of Teacher Education, 53 (5): 393-405. DOI: 10.1177/002248702237394

Handayanto, S. K. (2003). Strategi Pembelajaran Fisika. Malang: UNM

Hendayana, S., dkk. (2007). Lesson Study Suatu Strategi Untuk. Meningkatkan Keprofesionalan Pendidik. Bandung: FPMIPA UPI dan JICA.

Huda, K. (2016). Problematika Madrasah dalam Meningkatkan Mutu Pendidikan Islam. Dinamika Penelitian. 16 (2): 309-336

http://id.shvoong.com/books/dictionary/2117624-kelebihan-lessonstudy/\#ixzz27

MmC6zEO, diakses 1 Maret 2018

Sofyan Mahfudy \& Kurniawan Arizona (2021) "Peningkatan mutu pembelajaran.......| Vol. 1, No. 2, 2021 | h. 121 
Lewis, C.C, Perry, R.R, \& Hurd, J. (2009). Improving mathematics instruction through lesson study: a theoretical model and North American case. Journal of Mathematics Teacher Education. 12:285-304. DOI 10.1007/s10857-009-9102-7

Munirah. (2014). Upaya Peningkatan Mutu Hasil Belajar Melalui Media Pembelajaran. Auladuna. 1(1): $80-88$

Putri, W.N. (2017). Pengaruh Media Pembelajaran Terhadap Motivasi Belajar Bahasa Arab Siswa Madrasah Tsanawiyah. Lisania: Journal of Arabic Education and Literature. 1(1): 1-16. DOI: http://dx.doi.org/10.18326/lisania.v1i1.1-16

Sadiman, A dkk. (2012). Media Pendidikan, Jakarta: PT. RajaGrafindo Persada.

Sanjaya, W. 2011. Perencanaan dan Desain Sistem Pembelajaran. Jakarta: Kencana Prenada Media Group

Syukri, S. (2017). Konsep Pembelajaran Menurut Al-Qur’an. Ulumuna, 15(1), 1-28. https://doi.org/https://doi.org/10.20414/ujis.v15i1.206

Sofyan Mahfudy \& Kurniawan Arizona (2021) "Peningkeatan mutu pembelajaran....... | Vol. 1, No. 2, 2021 | h. 122 